\title{
One-Electron Oxidation of Hydrogen Sulfide by a Stable Oxidant: Hexachloroiridate(IV)
}

Ying $\mathrm{Hu}^{\dagger, t}$ and David M. Stanbury*

${ }^{\dagger}$ College of Chemical Engineering, China University of Mining and Technology, Xuzhou

221116, People's Republic of China

Dept. of Chemistry and Biochemistry, Auburn University, Auburn, AL 36849

\section{Supporting Information}

Tables S1 - S5; Figures S1-S5; details of the Marcus calculation. 


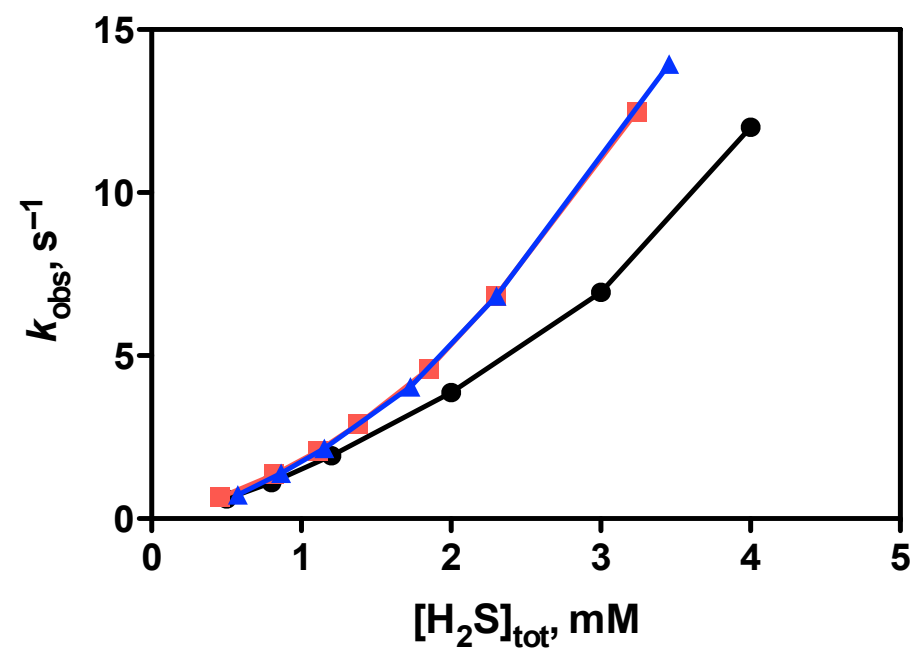

Figure S1. Dependence of $k_{\mathrm{obs}}$ on $\left[\mathrm{H}_{2} \mathrm{~S}\right]$ in the $\left[\mathrm{IrCl}_{6}\right]^{2-} / \mathrm{H}_{2} \mathrm{~S}$ reaction at three different dipic concentrations. $\left[\mathrm{Ir}^{\mathrm{IV}}\right]_{0}=0.05 \mathrm{mM}$, [dipic] $=1 \mathrm{mM}$ (black), $6 \mathrm{mM}$ (red), $10 \mathrm{mM}$ (blue). Acetate buffer at $\mathrm{pH} 4.7, \mu=0.1 \mathrm{M}, 25.0^{\circ} \mathrm{C}$.

Table S1. Dependence of $k_{\mathrm{obs}}$ on $\mathrm{pH}$ and $\left[\mathrm{H}_{2} \mathrm{~S}\right]$ in the $\left[\mathrm{IrCl}_{6}\right]^{2-}$-sulfide reaction with dipic. ${ }^{a}$

\begin{tabular}{cccccc}
\hline$\left[\mathrm{H}_{2} \mathrm{~S}\right]_{\text {tot }}, \mathrm{mM}$ & $\mathrm{pH} \mathrm{3.71}$ & $\mathrm{pH} \mathrm{3.95}$ & $\mathrm{pH} \mathrm{4.23}$ & $\mathrm{pH} \mathrm{4.51}$ & $\mathrm{pH} \mathrm{4.76}$ \\
\hline 2.5 & 0.373 & 0.679 & 1.61 & 3.44 & 6.51 \\
2.0 & 0.261 & 0.495 & 1.12 & 2.53 & 4.77 \\
1.5 & 0.171 & 0.326 & 0.787 & 1.79 & 3.27 \\
1.0 & 0.108 & 0.196 & 0.459 & 1.01 & 1.90 \\
0.5 & 0.048 & 0.086 & 0.188 & 0.412 & 0.735 \\
0.25 & 0.022 & 0.039 & 0.078 & 0.173 & 0.293 \\
\hline
\end{tabular}

${ }^{a}\left[\mathrm{Ir}^{\mathrm{IV}}\right]_{0}=0.05 \mathrm{mM},[$ dipic $]=6 \mathrm{mM}, \mu=0.1 \mathrm{M}$, acetate buffer, $25.0{ }^{\circ} \mathrm{C}$. 
Table S2. Fitted values of $k_{a}$ and $k_{b}$ with equation 1 at different $\mathrm{pH}^{a}$

\begin{tabular}{ccc}
\hline $\mathrm{pH}$ & $k_{a}, \mathrm{M}^{-1} \mathrm{~s}^{-1}$ & $k_{b}, \mathrm{M}^{-2} \mathrm{~s}^{-1}$ \\
\hline 3.71 & $80 \pm 7$ & $(2.6 \pm 0.4) \times 10^{4}$ \\
3.95 & $147 \pm 5$ & $(4.9 \pm 0.2) \times 10^{4}$ \\
4.23 & $(3.6 \pm 0.2) \times 10^{2}$ & $(1.15 \pm 0.09) \times 10^{5}$ \\
4.51 & $(8.2 \pm 0.6) \times 10^{2}$ & $(2.4 \pm 0.3) \times 10^{5}$ \\
4.51 & $(1.50 \pm 0.09) \times 10^{3}$ & $(4.7 \pm 0.5) \times 10^{5}$ \\
\hline
\end{tabular}

${ }^{a}$ Calculated from the data in Table S1. $\left[\mathrm{Ir}^{\mathrm{IV}}\right]_{0}=0.05 \mathrm{mM}$, [dipic] $=6 \mathrm{mM}, \mu=0.1 \mathrm{M}$, acetate buffer, $25.0{ }^{\circ} \mathrm{C}$.
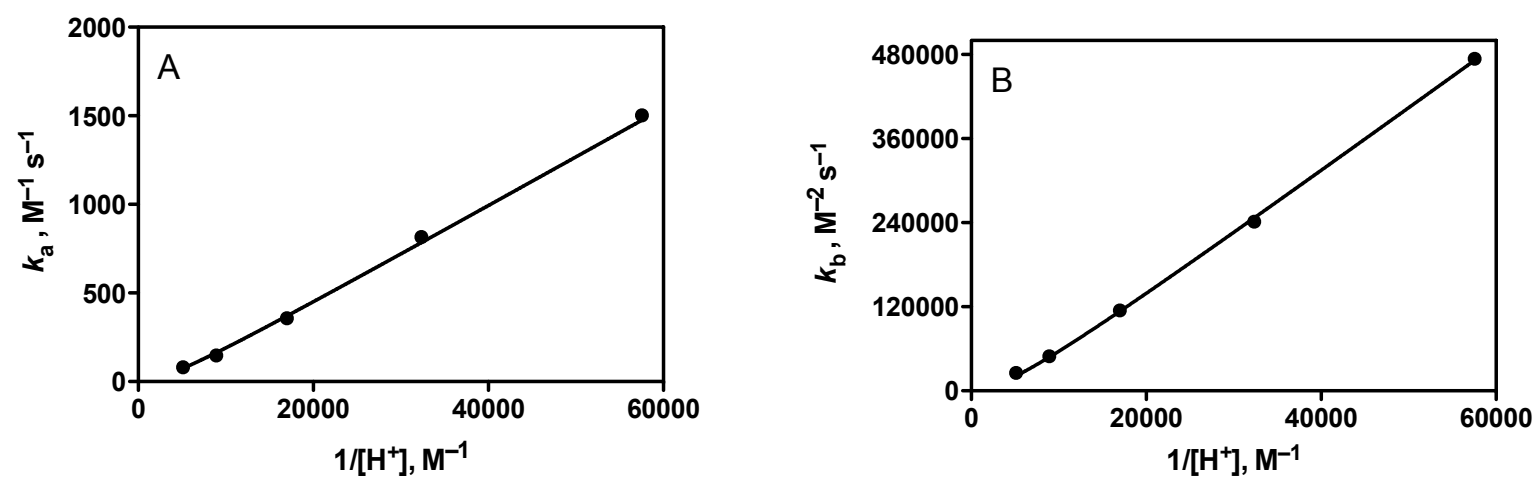

Figure S2. $\mathrm{pH}$ dependence of $k_{a}$ and $k_{b}$ in the $\left[\mathrm{IrCl}_{6}\right]^{2-}$-sulfide reaction. [dipic] $=6 \mathrm{mM}$. Solid lines are fits using eqs 2. Data from Table S2. 

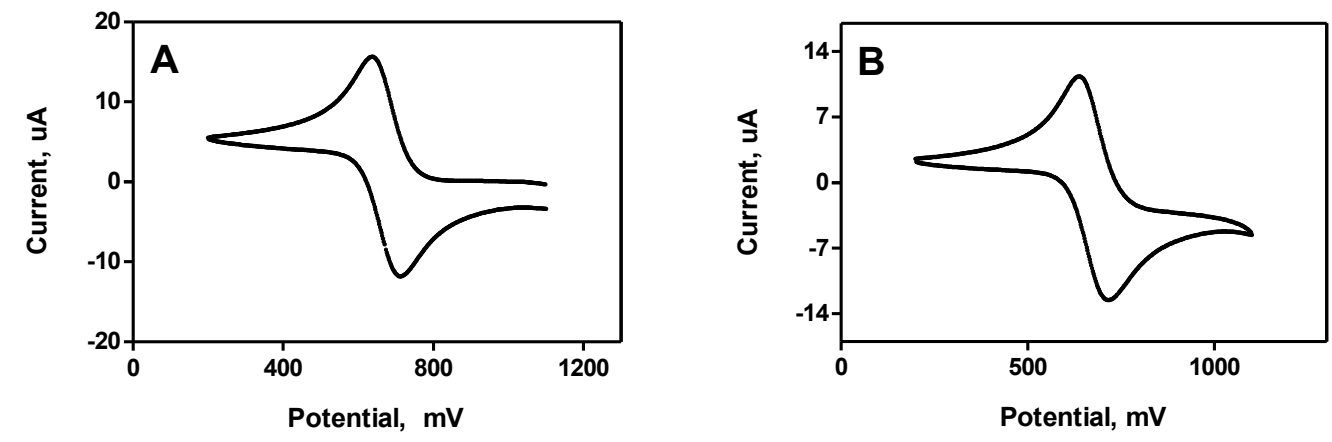

Figure S3. $\mathrm{CV}$ analysis of the $\left[\mathrm{IrCl}_{6}\right]^{2-}$ - sulfide reaction. (A) $\left[\mathrm{H}_{2} \mathrm{~S}\right]_{\mathrm{tot}}=0 \mathrm{mM}, E_{1 / 2}=0.677$ $(0.882 \mathrm{vs} \mathrm{NHE}) \mathrm{V}, \Delta E_{\mathrm{p} / \mathrm{p}}=0.072 \mathrm{~V}$; (B) $\left[\mathrm{H}_{2} \mathrm{~S}\right]_{\text {tot }}=0.5 \mathrm{mM}, E_{1 / 2}=0.676(0.882 \mathrm{vs} \mathrm{NHE}) \mathrm{V}, \Delta E_{\mathrm{p} / \mathrm{p}}$ $=0.072 \mathrm{~V}$. For both CVs $\left[\mathrm{Ir}^{\mathrm{IV}}\right]_{0}=1 \mathrm{mM}$, [dipic] $=10 \mathrm{mM}$, reference electrode $=\mathrm{Ag} / \mathrm{AgCl}$, glassy carbon working electrode, platinum wire counter electrode, Initial $E=1100 \mathrm{mV}$, high $E=$ $1100 \mathrm{mV}$, and low $E=200 \mathrm{mV}$.

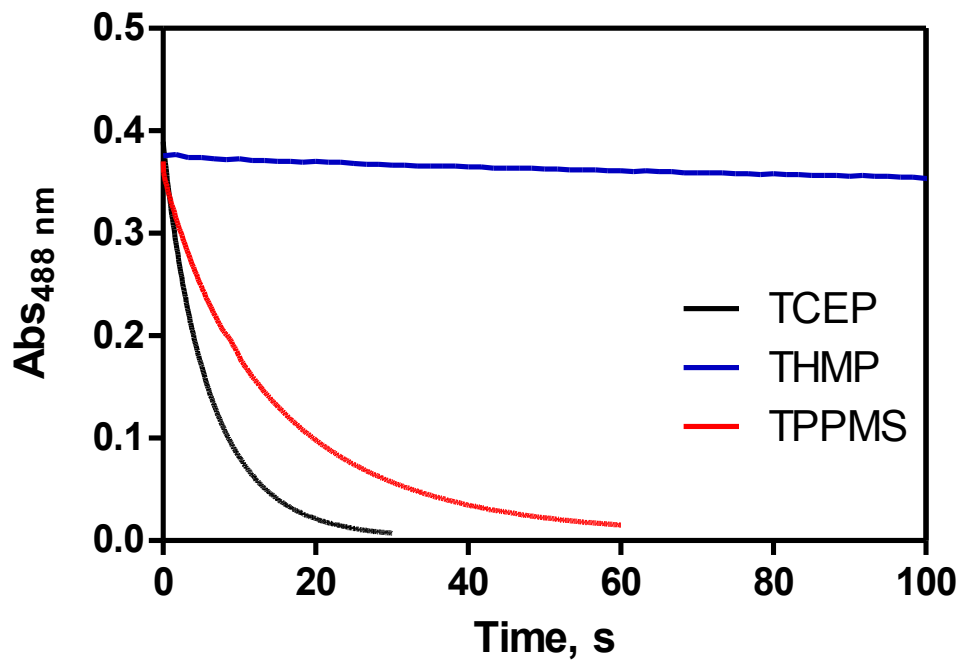

Figure S4. Kinetic traces of oxidation of phosphines by $\left[\mathrm{IrCl}_{6}\right]^{2-} \cdot\left[\mathrm{R}_{3} \mathrm{P}\right]=0.25 \mathrm{mM},\left[\mathrm{Ir}^{\mathrm{IV}}\right]_{0}=0.1$ $\mathrm{mM}$, [dipic] $=6 \mathrm{mM}, \mathrm{pH} 4.8$. 
Table S3. Comparison of the half-lives for direct oxidation of the phosphines and the oxidation of phosphine $/ \mathrm{H}_{2} \mathrm{~S}$ mixtures. ${ }^{a}$

\begin{tabular}{cccc}
\hline $\mathrm{R}_{3} \mathrm{P}$ & {$\left[\mathrm{R}_{3} \mathrm{P}\right], \mathrm{mM}$} & $t_{1 / 2}\left(\left[\mathrm{IrCl}_{6}\right]^{2-}-\mathrm{R}_{3} \mathrm{P}\right), \mathrm{s}$ & ratio $^{b}$ \\
\hline THMP & 5 & 60 & 150 \\
TPPMS & 0.15 & 21.3 & 53 \\
\hline
\end{tabular}

${ }^{a}\left[\operatorname{Ir}^{\mathrm{IV}}\right]_{0}=0.1 \mathrm{mM},[$ dipic $]=6 \mathrm{mM}, \mathrm{pH} 4.85 .{ }^{b}$ Ratio $=t_{1 / 2}\left(\left[\operatorname{IrCl}_{6}\right]^{2-}-\mathrm{R}_{3} \mathrm{P}\right) / t_{1 / 2}\left(\left[\operatorname{IrCl}_{6}\right]^{2-}-\mathrm{H}_{2} \mathrm{~S}-\mathrm{R}_{3} \mathrm{P}\right)$. $t_{1 / 2}\left(\left[\mathrm{IrCl}_{6}\right]^{2-}-\mathrm{H}_{2} \mathrm{~S}-\mathrm{R}_{3} \mathrm{P}\right)$ is about $0.41 \mathrm{~s},\left[\mathrm{H}_{2} \mathrm{~S}\right]_{\text {tot }}=2.5 \mathrm{mM}$, (as shown in Figure 5).

Table S4. Sulfide dependence of the kinetics of the $\left[\mathrm{IrCl}_{6}\right]^{2-}$ - sulfide reaction in the presence of THMP. $^{a}$

\begin{tabular}{ccccc}
\hline No. & {$\left[\mathrm{H}_{2} \mathrm{~S}\right]_{\text {tot }}, \mathrm{mM}$} & $k_{\mathrm{obs}}, \mathrm{s}^{-1}$ & $k_{\mathrm{obs}, \mathrm{THMP}}, \mathrm{s}^{-1}$ & $\Delta k_{\mathrm{obs}}, \mathrm{s}^{-1}$ \\
\hline 1 & 3.0 & 1.88 & & 1.87 \\
2 & 2.5 & 1.56 & & 1.55 \\
3 & 2.0 & 1.22 & & 1.20 \\
4 & 1.5 & 0.905 & 0.013 & 0.892 \\
5 & 1.0 & 0.606 & & 0.593 \\
6 & 0.5 & 0.310 & & 0.297
\end{tabular}

${ }^{a}[$ dipic $]=6 \mathrm{mM},[\mathrm{THMP}]=5 \mathrm{mM},\left[\mathrm{Ir}^{\mathrm{IV}}\right]_{0}=0.048 \mathrm{mM}, \mathrm{pH} 4.83$.

$k_{\text {obs }}$ is for the $\left[\mathrm{IrCl}_{6}\right]^{2-}-\mathrm{H}_{2} \mathrm{~S}$ reaction with both dipic and THMP.

$k_{\text {obs,THMP }}$ is for the $\left[\mathrm{IrCl}_{6}\right]^{2-}$ - THMP reaction with dipic.

$\Delta k_{\mathrm{obs}}=k_{\mathrm{obs}}-k_{\mathrm{obs}, \text { THMP. }}$ 
Table S5. $\mathrm{pH}$ dependence of the kinetics of the $\left[\mathrm{IrCl}_{6}\right]^{2-}$ - sulfide reaction in the presence of THMP. $^{a}$

\begin{tabular}{ccccc}
\hline No. & $k_{\text {obs, }} \mathrm{s}^{-1}$ & $k_{\text {obs,THMP }}, \mathrm{s}^{-1}$ & $\Delta k_{\text {obs },} \mathrm{s}^{-1}$ & $\mathrm{pH}$ \\
\hline 1 & 0.208 & 0.0095 & 0.199 & 3.961 \\
2 & 0.380 & 0.0104 & 0.369 & 4.256 \\
3 & 0.688 & 0.0115 & 0.677 & 4.525 \\
4 & 1.41 & 0.0128 & 1.40 & 4.786 \\
5 & 1.90 & 0.0134 & 1.89 & 4.955 \\
6 & 2.66 & 0.0124 & 2.65 & 5.113 \\
\hline
\end{tabular}

${ }^{a}[$ dipic $]=6 \mathrm{mM},[\mathrm{THMP}]=5 \mathrm{mM},\left[\mathrm{Ir}^{\mathrm{IV}}\right]_{0}=0.046 \mathrm{mM},\left[\mathrm{H}_{2} \mathrm{~S}\right]_{\mathrm{tot}}=2.5 \mathrm{mM}$. $k_{\text {obs }}$ is for the $\left[\mathrm{IrCl}_{6}\right]^{2-}-\mathrm{H}_{2} \mathrm{~S}$ reaction with both dipic and THMP. $k_{\mathrm{obs}, \mathrm{THMP}}$ is for the $\left[\mathrm{IrCl}_{6}\right]^{2-}$ - THMP reaction with dipic.

$\Delta k_{\mathrm{obs}}=k_{\mathrm{obs}}-k_{\mathrm{obs}, \mathrm{THMP}}$.

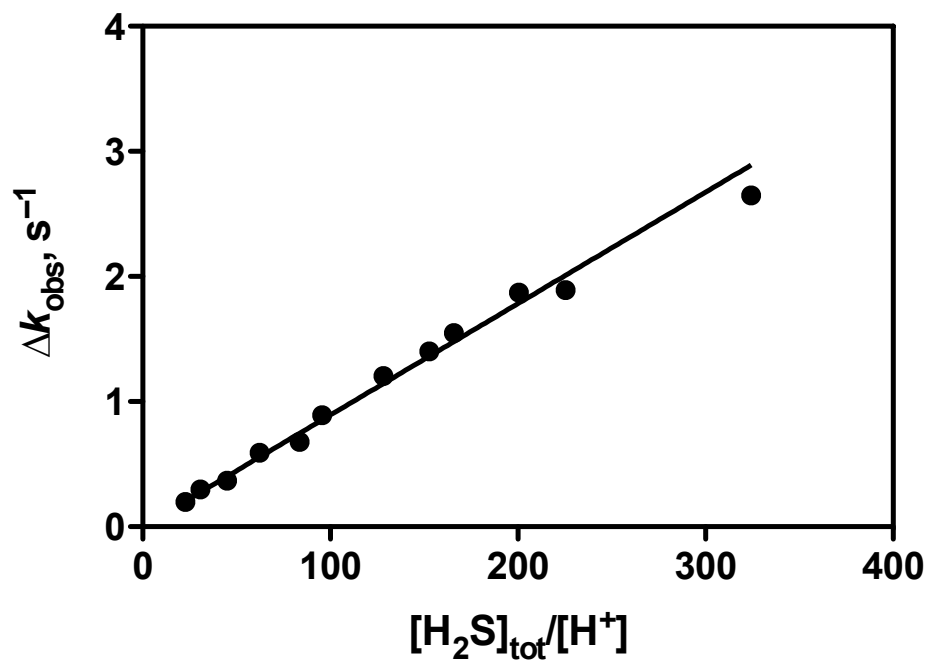

Figure S5. Plot of $\Delta k_{\text {obs }}$ vs $\left[\mathrm{H}_{2} \mathrm{~S}\right]_{\mathrm{tot}} /\left[\mathrm{H}^{+}\right]$for the $\left[\mathrm{IrCl}_{6}\right]^{2-}$ - sulfide reaction in the presence of dipic and THMP. Slope $=(8.9 \pm 0.3) \times 10^{-3} \mathrm{~s}^{-1}$. Data from Tables S4 and S5. 


\section{Details of the Marcus calculation}

The effective self-exchange rate constant for the $\mathrm{HS}^{\circ} / \mathrm{HS}^{-}$couple was calculated from the cross relationship of Marcus theory as given in the following equations: ${ }^{1}$

$$
\begin{aligned}
& k_{12}=\left(k_{11} k_{22} K_{12} f_{12}\right)^{1 / 2} W_{12} \\
& \ln f_{12}=\frac{\left[\ln K_{12}+\left(w_{12}-w_{21}\right) / R T\right]^{2}}{\left.4\left[\ln \left(k_{11} k_{22} / Z^{2}\right)+\left(w_{11}+w_{22}\right) / R T\right)\right]} \\
& W_{12}=\exp \left(-w_{12}-w_{21}+w_{11}+w_{22}\right) / 2 R T \\
& w_{i j}=4.23 Z_{i} Z_{j} /[r(1+0.328 r \sqrt{\mu})]
\end{aligned}
$$

For $k_{12}$ we used our experimental value for $k_{\mathrm{et}}: 2.9 \times 10^{4} \mathrm{M}^{-1} \mathrm{~s}^{-1}$. The self-exchange rate constant for $\mathrm{Ir}^{\mathrm{IV}} / \mathrm{Ir}^{\mathrm{III}}\left(k_{11}\right)$ was taken as $2 \times 10^{5} \mathrm{M}^{-1} \mathrm{~s}^{-1}{ }^{2} K_{12}$ was taken as $9.5 \times 10^{-5}$, calculated from the $E^{\circ}$ values for $\mathrm{Ir}^{\mathrm{IV}} / \mathrm{Ir}^{\mathrm{III}}$ and $\mathrm{HS}^{\circ} / \mathrm{HS}^{-}$. The ionic strength $(\mu)$ was $0.1 \mathrm{M}$. A radius of $4.1 \AA$ was assumed for the iridium complex, and a radius of $2 \AA$ was assumed for $\mathrm{HS}^{-}$. The value of $k_{22}$ (the $\mathrm{HS}^{*} / \mathrm{HS}^{-}$effective self-exchange rate constant) was then adjusted until good agreement was obtained between the measured and calculated values of $k_{12}$.

\section{References}

(1) Zuckerman, J. J. Inorganic Reactions and Methods, vol. 15, VCH: Deerfield Beach, FL, 1986; pp 13-47.

(2) Hurwitz, P.; Kustin, K. Trans. Faraday Soc. 1966, 62, 427-432. 